\title{
Caracterização Hidrogeológica da Bacia do Ribeirão Sobradinho - Brasília (DF)
}

\author{
J osé L G . Zoby \& Uniel Duarte \\ Departamento de Geologia Sedimentare Ambiental- Instituto de Geociências- USP \\ Rua do Lago 562, CEP 05508-900, São Paulo, SP
}

Palavras-chave: Bacia do Ribeirão Sobradinho, água subterrânea, domínios poroso e fraturado, qualidade físico-química e bacteriológica das águas.

\section{RESUMO}

A bacia do ribeirão Sobradinho se localiza na porção centro-norte do Distrito Federal e apresenta uma área de 144 $\mathrm{km}^{2}$. A água subterrânea se tornou importante alternativa de abastecimento para uma significativa parcela da população, pelo menos 22.500 pessoas.

A área estudada é representada geologicamente por metassedimentos de idade proterozóica, que encontram-se recobertos por espesso manto de intemperismo.

Foram individualizados, dentro do contexto hidrogeológico local, os domínios aqüíferos Poroso e Fraturado. O Domínio Fraturado foi classificado em dois sistemas denominados de Paranoá e Canastra. O Sistema Paranoá foi subdividido em quatro subsistemas aquíferos: Metarritmito Arenoso (média de vazões de $26,7 \mathrm{~m}^{3} / \mathrm{h}$ ), Quartzito (média de vazões de $8,7 \mathrm{~m}^{3} / \mathrm{h}$ ), Metarritmito Argiloso (média de vazões de $4,6 \mathrm{~m}^{3} / \mathrm{h}$ ) e Psamo-Pelito Carbonatado (média de vazões de $15,7 \mathrm{~m}^{3} /$ h). Como não foram cadastrados na área poços pertencentes ao Sistema Canastra, ele foi considerado indiviso. As principais fraturas produtoras nos poços concentram-se em profundidades de até $100 \mathrm{~m}$.

O Domínio Poroso está associado, na região, ao manto de intemperismo (solo e saprolito), que chega a mais de $100 \mathrm{~m}$ de espessura, sendo representado por aqüíferos livres, de grande continuidade lateral. A espessura e permeabilidade do manto de intemperismo apresentam grande controle em função do substrato geológico. O Domínio Poroso é explotado na região através de poços rasos.

A precipitação média anual na área estudada é de $1442,5 \mathrm{~mm}$. Cerca de $28 \%$ do volume precipitado participa da recarga dos aqüíferos.

O principal uso da água subterrânea é o domiciliar. As águas estudadas apresentam boa qualidade físico-química. A contaminação bacteriológica observada em amostras de água do manto de intemperismo está relacionada às deficiências construtivas dos poços rasos e à proximidade entre fossa e poço. Foram observadas deficiências técnicas construtivas em relação à proteção sanitária e aos processos de desativação e abandono dos poços profundos. 
Keywords: Sobradinho River basin, groundwater, porous and fractured domains, physico-chemical and bacteriological quality of waters.

\section{ABSTRACT}

The Sobradinho River basin comprises an area of $144 \mathrm{~km}^{2}$ in the north central portion of the Distrito Federal. Groundwater has become an effective alternative water supply for at least 22,500 persons in the basin.

The studied area is composed of metasedimentary Proterozoic covered by a thick weathered mantle. Hidrogeologicaly, a Porous Domain and a Fractured Domain have been individualized. The Fractured Domain is classified as the Paranoá and Canastra systems. The Paranoá System is subdivided into four aquifer systems: Metarritmito Arenoso (sandy metarhythmite with a mean yield $26.7 \mathrm{~m} / \mathrm{h}$ ), Quartzito (quartzite with a mean yield $8.7 \mathrm{~m}^{3} / \mathrm{h}$ ), Metarritmito Argiloso (argillaceous metarhytmite with a mean yield $4.6 \mathrm{~m}^{3} / \mathrm{h}$ ) and Psamo-Pelito Carbonatado (carbonate sandy pelite with a mean yield $15.7 \mathrm{~m}^{3} / \mathrm{h}$ ). As there are no wells in the Canastra System it remains undivided. The main producing fractures of the wells are limited to a depth of $100 \mathrm{~m}$.

The Porous Domain is related in the area to the weathered mantle (soil and weathered rock), which reaches more than $100 \mathrm{~m}$ in thickness, and is associated with unconfined aquifers of great lateral continuity. The thickness and permeability of the weathered mantle are strongly influenced by the geological basement. The Porous Domain is exploited in the studied area by excavated wells.

Of the mean annual rainfall in the area $(1,442.5 \mathrm{~mm})$, approximately $28 \%$ is involved in the aquifer recharge.

The main use of the groundwater, which presents good physical-chemical qualities, is domestic. Bacteriological contamination in water samples from the weathered mantle is related to technical deficiencies in construction of the excavated wells and the proximity of cesspools. Problems with sanitary protection and procedures of deactivation and abandoning of the deep groundwater wells have been recognized.

\section{INTRODUÇÃO}

O Distrito Federal (DF) foi planejado para abrigar a capital do país, uma cidade de médio porte (Brasília), e suas cidades satélites (Taguatinga, Planaltina, Brazlândia, Sobradinho entre outras), que deveriam ser circundadas por um cinturão verde. Passadas mais de três décadas da sua fundação, a região apresenta um nível de desenvolvimento e crescimento muito acima daqueles previstos inicialmente.

O censo demográfico revelou no ano de 1991, população de cerca de 1.600 .000 habitantes, quando o valor previsto para o ano 2000 era de apenas 500.000 habitantes. A comparação com dados censitários anteriores revela que a população aumentou cerca de 11 vezes no período entre os censos de 1960 e 1991, um processo que está ligado principalmente ao efeito da migração. Como conseqüência deste crescimento demográfico, desenvolveram-se basicamente os setores de comércio e de serviços. Na área rural, a expansão das atividades agropecuárias foi significativa.

Desta forma, o DF se transformou rapidamente em um pólo de desenvolvimento que gerou uma significativa mudança no quadro de ocupação e de expansão da região. Uma das características deste processo foi o seu elevado grau de urbanização, que produziu uma defasagem nos serviços básicos como esgotos, energia elétrica e abaste- cimento de água. Surgiu também uma série de problemas ambientais como diferentes formas de poluição do ar, solo e águas, redução da vegetação natural e surgimento de processos erosivos superficiais e subterrâneos. Recentemente têm surgido também discussões sobre questões como a disposição dos resíduos sólidos e localização de aterros sanitários.

O gerenciamento do recurso hídrico é uma questão que vem se tornando cada vez mais importante no DF, não apenas pelo aumento da demanda de água, mas também pelos impactos ambientais relacionados ao lançamento de esgotos domésticos sem tratamento, a utilização indiscriminada de agrotóxicos, a erosão e o assoreamento de rios, entre outros.

O abastecimento de água no DF é realizado através da captação de águas superficiais dos sistemas Santa Maria/ Torto e do Descoberto, sendo complementado por dezessete pequenas e médias captações. Este quadro é relativamente preocupante em função do crescimento da demanda e também das caraterísticas geomorfológicas da região, cuja área é constituída de terras altas que funcionam como dispersoras das drenagens. Os rios da região são de pequeno a médio porte, por isso pequenas e médias captações são utilizadas para suprir regiões com alto déficit de abastecimento.

A água subterrânea vem se apresentando como uma alternativa complementar ao abastecimento por águas su- 


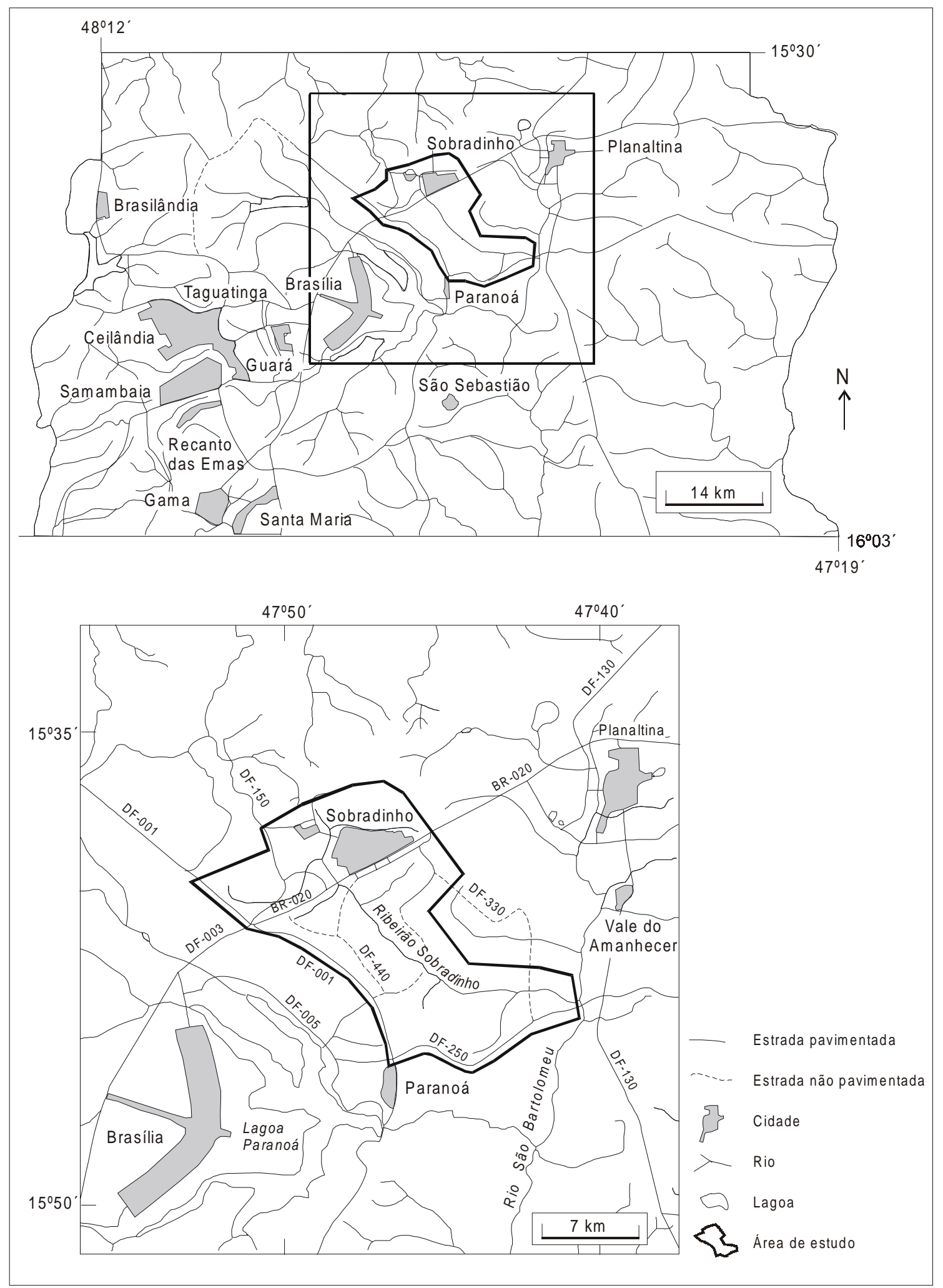

Figura 1: Loca lização da área de estudo. 
perficiais. A CAESB (Companhia de Água e Esgotos de Brasília) atualmente utiliza a água subterrânea para abastecer comunidades rurais e de forma complementar em áreas urbanas. A cidade satélite de São Sebastião entretanto, é totalmente abastecida por poços tubulares profundos.

A grande demanda pelo recurso hídrico subterrâneo na região vem dos denominados condomínios, que surgiram do parcelamento irregular do solo. No ano de 1996, o DF apresentava 530 condomínios, dos quais 232 foram considerados como já implantados (IPDF, 1996). Esses loteamentos tornaram-se ao longo dos anos uma importante oportunidade de acesso à moradia, especialmente para a classe média. Por outro lado, criaram uma série de impactos ambientais, aos quais somam-se problemas de infraestrutura, como de esgotamento sanitário e rede pluvial. $\mathrm{O}$ abastecimento de água nestes locais vem sendo realizado por iniciativa individual para cada parcelamento, pelos próprios moradores ou pelo empreendedor, sendo a maior parte através de água subterrânea, na forma de poços tubulares profundos e também de poços rasos (cacimbas).

A bacia do ribeirão Sobradinho é um exemplo desta situação. Ela localiza-se na região centro-norte do DF, possui uma área de drenagem de aproximadamente 144 $\mathrm{km}^{2}$ e faz parte da bacia do rio São Bartolomeu, a maior do DF (Figura 1). A característica marcante desta área é o intenso processo de parcelamento do solo, que se intensificou principalmente na década de 90 . Atualmente a região encontra-se densamente povoada, apresentando alguns dos condomínios mais antigos e consolidados do DF, que têm na sua maior parte a água subterrânea como principal fonte de abastecimento. O assentamento Sobradinho II até 1997 era abastecido exclusivamente através de poços tubulares profundos. Alguns dos aqüíferos mais importantes do DF ocorrem na região. Além disso, como o processo de ocupação do solo na região ainda continua, a demanda pelo recurso hídrico subterrâneo tende a crescer.

Apesar do crescente interesse pela explotação dos aqüíferos da região, o que se verifica é a escassez de estudos sobre o recurso hídrico que permitam subsidiar processos decisórios que levem em conta a sua sustentabilidade. No DF existe uma carência de estudos hidrogeológicos detalhados, já que aqueles disponíveis são de caráter regional. Surgem portanto, questionamentos sobre o potencial hídrico dos aquíferos da região, seu atual estágio de explotação e da necessidade de proteção das águas subterrâneas.

O estudo buscou, neste sentido, contribuir para um melhor conhecimento dos aquíferos da área de estudo e avaliar a qualidade da água subterrânea. Os resultados obtidos tiveram como objetivo fornecer subsídios para a gestão dos recursos hídricos subterrâneos na bacia do ri- beirão Sobradinho, de modo a compatibilizar um desenvolvimento sustentável de sua explotação.

\section{CARACTERIZAÇÃO DA ÁREA DE ESTUDO}

\section{Aspectos de uso e ocupação do solo}

A Região Administrativa de Sobradinho, que inclui as cidades de Sobradinho e o assentamento Sobradinho II, apresentava em 1991 uma população de cerca de 81.000 habitantes, da qual $83 \%$ estava concentrada em área urbana. Embora definidos como rurais, as áreas de loteamentos e condomínios da região, na verdade se constituem como núcleos urbanos ou semi-urbanos. Ou seja, a maior parte da população da Região Administrativa de Sobradinho, considerada como da área rural, ocupa na verdade áreas com características de zona urbana.

A cidade de Sobradinho e o assentamento Sobradinho II são abastecidas pelas captações dos córregos Contagem, Paranoazinho e Corguinho. O assentamento Sobradinho II foi abastecido até 1997 através de cinco poços tubulares. Com a construção de uma adutora a partir de Sobradinho, os poços foram desativados e a água subterrânea substituída pela superficial.

O parcelamento e desmembramento de áreas rurais são as principais características da região. A dinâmica populacional vem sendo marcada pela demanda habitacional que se realiza através dos condomínios e loteamentos em zonas rurais. Nestes locais não existe infraestrutura sanitária e o abastecimento de água é realizado, na sua grande maioria, através de poços tubulares profundos. Na Região Administrativa de Sobradinho em 1996 existia um total de 75 parcelamentos do solo em processo de regularização (GDF, 1996).

\section{Aspectos físicos}

O Distrito Federal está situado no Planalto Central e apresenta como elemento marcante na sua paisagem as chapadas, extensas superfícies de relevo plano a suave ondulado, intercaladas por níveis arrasados. A região está localizada em uma área divisora de bacia na qual os rios são, em geral, de pequeno porte.

O ribeirão Sobradinho pertence à bacia do rio São Bartolomeu. Nasce no Morro da Canastra, próximo à cidade de Sobradinho, e segue em direção SE até quase sua confluência com o rio São Bartolomeu, onde então muda 
para uma direção aproximada EW. Apresenta uma amplitude altimétrica de aproximadamente $350 \mathrm{~m}$. O padrão de drenagem da bacia é retangular, no trecho em que afloram as litologias do Grupo Paranoá, sugerindo forte controle estrutural.

A área de estudo se insere em dois grandes compartimentos geomorfológicos denominados de Chapadas e Vales Dissecados (Novaes Pinto, 1986, 1994). O trecho no qual o ribeirão Sobradinho apresenta direção NW corresponde à unidade da Chapada da Contagem. $\mathrm{O}$ curso inferior deste ribeirão, de direção E-W, é classificado como região de Vale Dissecado do Alto Curso do rio São Bartolomeu.
Sob o aspecto geológico, o Distrito Federal está localizado na transição entre as zonas externa e interna da Faixa Brasília, tendo sido reconhecidas rochas pertencentes aos grupos Canastra, Araxá, Paranoá e Bambuí (Figura 2). Na área de estudo são identificadas rochas pertencentes aos grupos Paranoá e Canastra.

O Grupo Paranoá é a unidade de mais ampla distribuição no DF ocupando cerca de $65 \%$ da área do DF. A sua estratigrafia na região é representada por seis unidades que, da base para o topo, são $\mathrm{S}, \mathrm{A}, \mathrm{R}_{3}, \mathrm{Q}_{3}, \mathrm{R}_{4}$ e PPC (FreitasSilva \& Campos, 1998). Na área de estudo ocorrem litologias pertencentes às unidades de topo $\mathrm{R}_{3}, \mathrm{Q}_{3}, \mathrm{R}_{4} \mathrm{e}$ PPC.

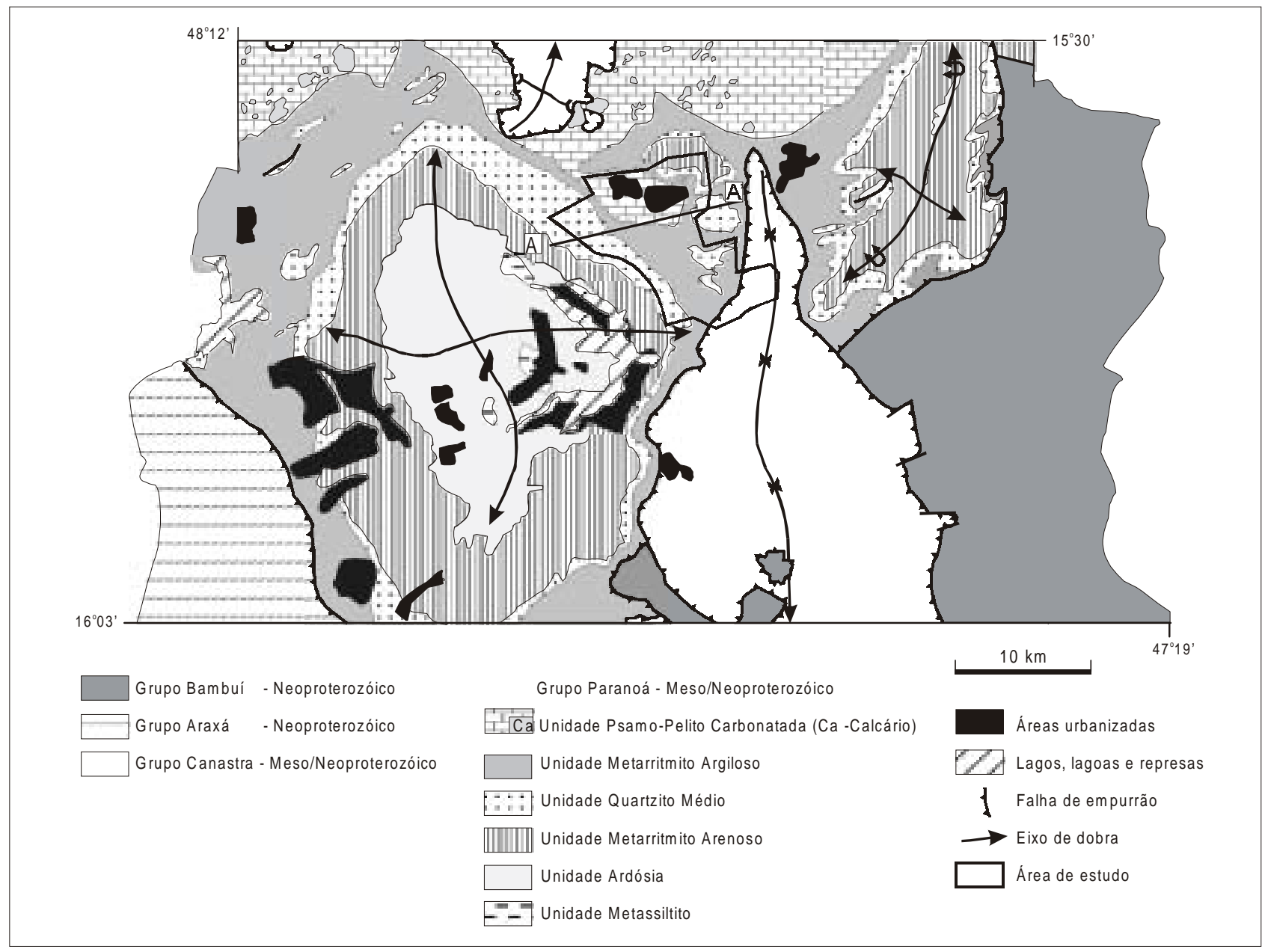

Figura 2: Mapa geológic o do Distrito Federal (Freitas-Silva \& Campos, 1998). 
A unidade Metarritmito Arenoso $\left(\mathrm{R}_{3}\right)$ é caracterizada pela alternância de estratos centimétricos a métricos de quartzitos finos a médios, com níveis geralmente mais delgados de metassiltitos argilosos, metalamitos siltosos e metalamitos micáceos. A unidade Quartzitos Médios $\left(\mathrm{Q}_{3}\right)$ apresenta contato brusco e concordante com a unidade sotoposta. É composta por quartzitos finos a médios muito localmente grossos, bem selecionados, em geral, muito silicificados. Lentes de metarritmitos com espessura decimétricas de até $10 \mathrm{~m}$ ocorrem geralmente próximas a base e ao topo.

A unidade Metarritmito Argiloso $\left(\mathrm{R}_{4}\right)$ é formada por um metarritmito homogêneo com intercalações centimétricas regulares de metassiltitos, metalamitos e quartzitos finos. Localmente ocorrem níveis $(50 \mathrm{~cm}$ até $1 \mathrm{~m})$ de metassiltitos maciços e quartzitos finos feldspáticos. Seu contato com a unidade $\mathrm{Q}_{3}$ é gradacional.

A unidade Psamo-Pelito-Carbonatada (PPC) apresenta contato transicional com a $\mathrm{R}_{4}$, sendo composta por metalamitos siltosos bastante laminados e intercalações de rochas quartzítcas e carbonáticas. As rochas carbonáticas são representadas por calcários e subordinadamente, por dolomitos localmente estromatolíticos, que ocorrem como lentes de centenas de metros, podendo alcançar mais de um quilômetro. Na região de interdigitação entre as lentes carbonáticas e as rochas pelíticas, são comuns as fácies de metamargas. Ocorrem ainda, lentes métricas a decamétricas ou em níveis centimétricos de quartzitos médios, grossos a conglomeráticos, que podem apresentar certa ritmicidade.

O Grupo Canastra ocorre de forma restrita na área de estudo, próximo à confluência do ribeirão Sobradinho com o rio São Bartolomeu. A unidade caracteriza-se por um conjunto amplamente dominado por filitos variados (clorita filitos, quartzo-sericita-clorita filitos, sericita filitos) com contribuição restrita de quartzitos, calcifilitos, mármores e filitos carbonosos (Freitas-Silva \& Campos, 1998).

O conhecimento atual revela que a deformação impressa nos litotipos presentes no Distrito Federal está relacionada à tectônica Brasiliana, que afetou o conjunto da zona externa da Faixa Brasília, por volta de $650 \mathrm{Ma}$. A megaestruturação do DF é condicionada pelo padrão de interferência dos dobramentos (Faria, 1995; Freitas-Silva \& Campos, 1998), cujos principais exemplos são os domos estruturais do Brasília, do Pipiripau e de Sobradinho, e pelo arranjo e cronologia relativa de três grandes sistemas de cavalgamento denominados de Paranã, São Bartolomeu/ Maranhão e Descoberto (Freitas-Silva \& Campos, 1998). Foram identificadas cinco fases de deformação denominadas de $\mathrm{F}_{1}$ a $\mathrm{F}_{5}$. Com exceção da última fase $\left(\mathrm{F}_{5}\right)$, de caráter eminentemente rúptil, as demais são caracterizadas por estruturas dúcteis-rúpteis representadas por planos de cavalgamento e dobramentos (Freitas-Silva \& Campos, 1998).

A tectônica atuante na região durante o Paleozóico e o Cenozóico é ainda pouco estudada. As reativações tectônicas possivelmente tiveram importância fundamental sobre os processos intempéricos e erosivos, responsáveis pela compartimentação geomorfológica do DF. Alguns estudos vêm descrevendo evidências de eventos de deformação pós-proterozóicos observados principalmente em perfis do manto de intemperismo (Campos \& FreitasSilva 1998, Martins et al., 1994, Blanco, 1995)

$\mathrm{Na}$ área de estudo, de acordo com o mapa de solos da EMBRAPA (1978), predominam amplamente os latossolos (vermelho escuro, vermelho-amarelo e concrecionários) e cambissolos/litólicos. Subordinadamente ocorrem os solos hidromórficos e areias quartzosas.

Os latossolos caracterizam-se basicamente por terem sofrido lixiviação intensa dos elementos básicos com a acumulação de óxidos de ferro e de alumínio (EMBRAPA, 1978). Apesar de apresentarem altos teores de argila, são essencialmente constituídos por argilominerais do tipo 1:1, resultando em baixas capacidades de retenção de água e de troca iônica, e alta infiltração, comportando-se em quase todo o perfil como solos de textura mais grossa (Haridasan, 1994).

Os cambissolos e solos litólicos ocupam as áreas de relevo ondulado a fortemente acidentado do vale do rio São Bartolomeu. Os cambissolos são solos jovens e pouco profundos, sendo comum a presença de minerais primários e a conservação de algumas estruturas originais da rocha matriz (Haridasan, 1994). Apresentam, em geral, cascalhos, concreções e fragmentos de rochas ao longo dos perfis, concentrando-se a maior parte na superfície do solo (EMBRAPA, 1978). Os solos litólicos são pouco desenvolvidos, apresentando textura quase sempre de cascalho, e ocorrem associados aos cambissolos.

\section{Caracterização climática e balanço hídrico}

De acordo com a classificação de Köppen, o clima do DF enquadra-se entre os tipos Tropical (Aw) e Tropical de Altitude (Cwa e Cwb) (CODEPLAN, 1984). A sua característica marcante é a existência de duas estações bem definidas: chuvosa no verão e seca no inverno. O período chuvoso corresponde aos meses de outubro a abril e o seco se estende de maio a setembro.

A caracterização climatológica da área de estudo foi realizada a partir dos dados da estação climatológica da 
EMBRAPA (Empresa Brasileira de Pesquisa Agropecuária) e da estação pluviométrica de Sobradinho. A fim de permitir uma melhor caracterização da precipitação média de chuva na bacia, foram utilizados também os dados pluviométricos das 3 estações mais próximas da área estudada, que são Contagem, Paranoá e Colégio Agrícola (Figura 3).

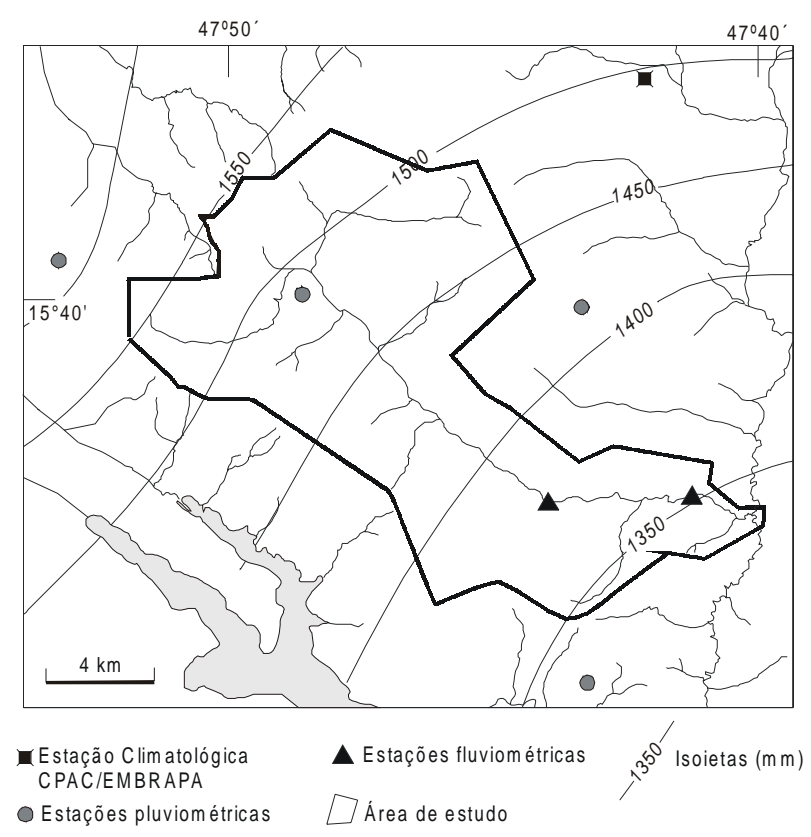

Figura 3: Mapa de isoietas da área de estudo e de localização dasestaçõeshidrológicas.

O ribeirão Sobradinho apresenta duas estações de medição da descarga fluvial (Figura 3). Na análise dos dados, optou-se pela utilização dos dados da estação mais a montante, por apresentar uma série histórica maior de 18 anos (1978 a 1995), contra a outra iniciada a partir de 1994.

Foram levantados dados mensais e anuais das variáveis meteorológicas destas estações. Como existem diferenças no período de observação das diferentes estações adotadas, optou-se pela utilização dos dados de 1979 a 1995, a fim de se obter maior coerência na comparação e avaliação dos resultados, já que para esse período os dados disponíveis são bastante completos.

A distribuição das chuvas ao longo do ano é bastante irregular na área de estudo. A estação pluviométrica de Sobradinho apresenta nos meses mais chuvosos, que são novembro, dezembro e janeiro, uma precipitação média de $725,5 \mathrm{~mm}$, ou seja, o trimestre concentra $49,9 \%$ da pre- cipitação média anual (1453 mm). Por outro lado, praticamente não chove na época seca. O trimestre mais seco, que vai de junho a agosto, apresenta precipitação média de cerca de $35 \mathrm{~mm}$.

A temperatura média anual na área é de $22^{\circ} \mathrm{C}$, enquanto a mínima e a máxima são respectivamente, de 16,3 e $27,6^{\circ} \mathrm{C}$. Os meses mais frios vão de maio a agosto e correspondem, aproximadamente, à estação seca (maio a setembro). Os meses mais quentes são setembro, outubro e novembro, e apresentam temperaturas médias oscilando entre 22,8 e $23,3^{\circ} \mathrm{C}$.

$\mathrm{O}$ aspecto mais característico da área estudada e do clima do DF no período de seca é a diminuição da umidade relativa do ar, sobretudo no período mais quente do dia entre as 12 e 15 horas, quando os valores chegam a menos de $20 \%$. Entretanto, devido à variabilidade diária da temperatura (amplitudes médias superiores a $11^{\circ} \mathrm{C}$ ), os valores médios diários são mais elevados ficando entre 57 e $71 \%$. Na estação chuvosa os valores médios mensais são superiores a $70 \%$.

Para a determinação do balanço hídrico de uma bacia hidrográfica, é fundamental a determinação da altura média de precipitação. Esta análise foi feita com base em totais anuais, a fim de se obter representatividade das disponibilidades hídricas da bacia no decorrer do período escolhido para análise. Entre as metodologias clássicas mais utilizadas para a determinação da precipitação média em uma área foi utilizado o Método das Isoietas. Foi utilizada como função de interpolação no traçado das isoietas a krigagem (Figura 3), tendo sido obtida uma precipitação média anual de $1442,5 \mathrm{~mm}$ para a área.

O balanço hídrico relaciona as entradas e saídas de água que ocorrem em uma área durante um certo período de tempo. A sua utilização em estudos hidrogeológicos visa estimar a quantidade de água disponível que participa da recarga dos aqüíferos. É importante ressaltar que o balanço hídrico aplicado buscou estimar a ordem de magnitude e importância dos termos que o compõem, através de valores médios anuais, e por isso algumas simplificações foram feitas.

Uma das formas de se descrever o balanço hídrico pode ser expressa através da seguinte relação (Custódio \& Llamas, 1996):

$$
\mathrm{P}=\mathrm{ETR}+\mathrm{EX}+\mathrm{DR}
$$

sendo ETR a evapotranspiração real, EX os excedentes de água, representados pelo escoamento superficial e a infiltração, e DR a variação na reserva de água no solo utilizável pelas plantas.

O termo DR é também conhecido como capacidade de armazenamento (CA), que é um valor compreendido en- 
tre a capacidade de campo do solo e o ponto de murchamento permanente, a partir do qual as plantas não conseguem mais retirar do solo a água capilar (Custódio \& Llamas, 1996). O armazenamento de água no solo pode ser desprezado no balanço hídrico desde que o período ao qual se aplica o método seja relativamente longo, ou seja, da ordem de um ano, pois o ciclo hidrológico é um sistema fechado sem perda ou criação de água (Ometo, 1981 apud Cicco et al., 1985). Como na presente análise, o período avaliado é de 17 anos, a variação na quantidade de água disponível no solo para as plantas (DR) foi considerado desprezível.

$\mathrm{Na}$ equação do balanço hídrico falta determinar portanto, o termo EX, representado pelos escoamentos subterrâneo e superficial, e a evapotranspiração real (ETR). Em estudos hidrogeológicos o termo mais importante em um balanço hidrológico é representado pelo volume de água que infiltra no subsolo e efetivamente alcança o aqüífero, que pode ser determinado através dos hidrogramas dos rios por métodos gráficos. Existem diferentes formas de separar em um hidrograma o escoamento superficial do subterrâneo. Foi adotado, neste estudo, o método de Barnes que apresenta os resultados mais confiáveis (Custódio \& Llamas, 1996).

A análise do hidrograma (Figura 4) através do método de Barnes indicou um volume médio infiltrado (escoamento subterrâneo) anualmente equivalente a $410 \mathrm{~mm}$, e de escoamento superficial equivalente a $243 \mathrm{~mm}$. A diferença entre a média de precipitação da bacia $(1442,5 \mathrm{~mm})$ e a soma dos escoamentos subterrâneo e superficial (termo EX) fornece um valor de $789,5 \mathrm{~mm}$, que pode ser considerado uma estimativa da evapotranspiração real na bacia. A evapotranspiração real na bacia representa portanto, $54,7 \%$ da média anual de chuva. Este valor é bastante razoável, pois Coimbra (1987) obteve para a bacia do rio São Bartolomeu, e que inclui portanto a área de estudo, um valor de $884,2 \mathrm{~mm}$ para a evapotranspiração real.

\section{HIDROGEOLOGIA}

Dentro do contexto hidrogeológico da área podem ser diferenciados dois grandes grupos de aqǘferos, que correspondem aos tipos clássicos: o Domínio Poroso e o Domínio Fraturado.

\section{Domínio Poroso}

Corresponde na região estudada ao manto de intemperismo e, de forma mais restrita, aos aluviões, que caracterizam-se como meios geológicos inconsolidados, essencialmente porosos.

Este sistema aqǘf́ero compõe o sistema de águas subterrâneas rasas. Apresenta importância local significativa, sendo responsável pelo abastecimento principalmente da população rural e de alguns condomínios da região, através de poços rasos e, subordinadamente, através de fontes.

O manto de intemperismo ou regolito da região é representado pelos solos e saprolitos que recobrem a rocha sã. Eles constituem um meio não consolidado formando um sistema contínuo de grande extensão e continuidade lateral, recobrindo praticamente $99 \%$ da área estudada. São aqüíferos livres e, de forma mais restrita, supensos.

Em continuidade hidráulica e, portanto, integrando este sistema aquífero, ocorrem os aluviões, que são muito pouco expressivos na área e não têm praticamente nenhuma participação no abastecimento da população através de água subterrânea. Estão restritos aos vales dos ribeirões da região, sendo o mais importante aquele que acompanha a calha de drenagem do ribeirão Sobradinho. Os aluviões estão associados a solos hidromórficos principalmente na porção norte da bacia. São limitados lateralmente e pouco espessos, apresentando sedimentos mal selecionados, com granulometria de argila até areia média.

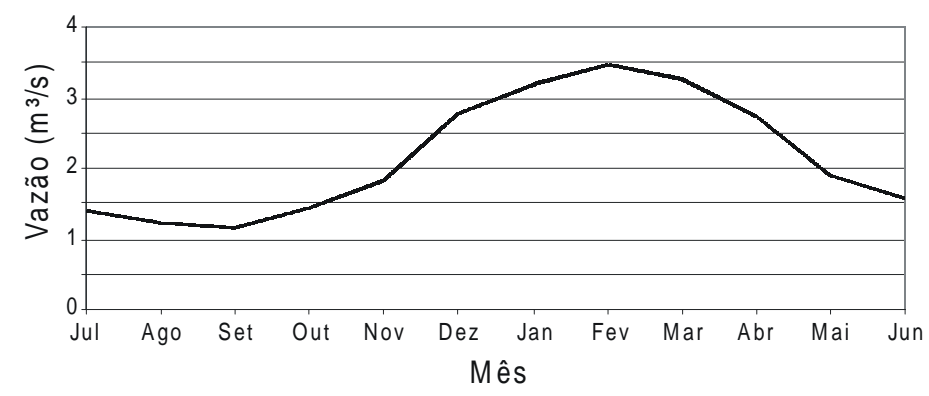

Figura 4: Hid rogra ma do ribeirã o Sobrad inho (valores médiosmensa isc orrespondentesao perío do de 1979 a 1995). 
O manto de intemperismo desempenha importante papel dentro do contexto hidrogeológico da área de estudo. A zona não saturada é muito importante para a recarga do aquiífero freático e atua como proteção do aqüífero à contaminação antrópica. Além disso, a zona saturada do saprolito, por encontrar-se em contato direto sobre a rocha sã, exerce importante função nas condições de recarga das fraturas, que compõem o aqüífero fraturado subjacente. Finalmente o manto de intemperismo, por sua grande extensão e continuidade, é responsável pela manutenção da perenidade das drenagens durante o período de seca.

A caracterização do perfil de intemperismo na área, estabelecido principalmente a partir dos perfis litológicos dos poços profundos, mostra forte controle do tipo litológico subjacente, que influi diretamente na espessura e nas características granulométricas e mineralógicas, que controlam as propriedades hidráulicas destes meios.

As unidades $\mathrm{Q}_{3}$ (Quartzito Médio) e $\mathrm{R}_{3}$ (Metarritmito Arenoso) do Grupo Paranoá sustentam as porções topograficamente mais elevadas da área de estudo. Como nestas unidades a presença de termos psamíticos, principalmente quartzitos, é muito significativa, o manto de intemperismo é menos desenvolvido, quando comparado àquele que ocorre nas regiões de encosta e de vale, associado às unidades de caráter mais pelítico (unidades Metarritmito Argiloso e Psamo-Pelito Carbonatada).

$\mathrm{O}$ regolito associado à unidade $\mathrm{Q}_{3}$ é relativamente menos profundo, com espessura média de $12,5 \mathrm{~m}$, enquanto que aquele associado à unidade $\mathrm{R}_{3}$, em função da significativa presença de níveis pelíticos favorece o desenvolvimento de um manto de intemperismo mais espesso, com média de $58,7 \mathrm{~m}$.

Os solos associados às unidades $\mathrm{R}_{3}$ e $\mathrm{Q}_{3}$ são representados, predominantemente, por latossolos vermelhos escuros a marrons e localmente ocorrem solos arenosos. São solos predominantemente residuais e naqueles associados aos quartzitos, o processo de laterização, em geral, é incipiente.

O conjunto solo e saprolito nestes locais apresenta granulometria essencialmente arenosa a siltosa, o que reflete em condutividade hidráulica relativamente elevada. A Planidro (1970) obteve uma condutividade hidráulica de $10^{-4} \mathrm{~cm} / \mathrm{s}$, equivalente a areia fina, em manto de desagregação de quartzito de 24 m próximo à área de estudo. Como este manto de intemperismo apresenta boas condições de permeabilidade e ocorre nas regiões mais elevadas, a sua participação na recarga dos aquiíferos da região é muito importante.

As litologias mais susceptíveis aos processos de intemperismo químico na área de estudo são os metargilitos e metassiltitos. Por isso, o manto de intemperismo associado ao substrato formado essencialmente por rochas pelíticas é significativamente mais profundo. As transições entre solo/saprolito e saprolito/rocha são muitas vezes imprecisos e de difícil definição. Este manto de intemperismo espesso ocorre nas regiões de encosta e de vale da bacia, e corresponde à ocorrência das unidades Metarritmito Argiloso $\left(\mathrm{R}_{4}\right)$ e Psamo-Pelito-Carbonatada (PPC). As espessuras médias do regolito sobre as unidades $\mathrm{R}_{4}$ e PPC são respectivamente, de 83,8 e 46,6 m.

Os solos associados são representados por latossolos vermelho escuros e de forma subordinada, amarelos a marrons, de textura argilosa ou sílitico-argilosa. Entretanto, estes solos apresentam em geral permeabilidade e porosidade elevadas. Mortari (1994) considera que a estrutura "castelo de cartas", observada nestes solos, é mantida pelas cimentações que promovem a formação de estrutura granular, apesar da matriz argilosa, com comportamento em termos de infiltração similar aos solos granulares $\left(10^{-3}\right.$ a $\left.10^{-4} \mathrm{~cm} / \mathrm{s}\right)$. Estudo geotécnico de solo recobrindo metarritmito argiloso na região de Sobradinho, indicou frações de argila, silte e areia respectivamente, de $50,5 \%, 9,5 \%$ e $40 \%$, com porosidade de $57,5 \%$ e condutividade hidráulica entre $10^{-5}$ e $2,4 \times 10^{-4} \mathrm{~cm} / \mathrm{s}$ (Mortari, 1994).

Os saprolitos associados às unidades $\mathrm{R}_{4}$ e PPC apresentam espessuras bastante variáveis, em função do grau de intemperismo e tipo litológico do substrato. Quando existem camadas expressivas de quartzitos, rocha mais resistente aos agentes intempéricos, o saprolito é, em geral, menos espesso e o contato saprolito/rocha é bem definido. Quando o substrato é composto por metapelitos a transição saprolito/rocha não é bem definida, e como são rochas muito susceptíveis ao intemperismo, os saprolitos são mais espessos. Estas feições determinam significativas variações laterais dos saprolitos na área.

Em pacotes de metarritmitos, em que se alternam níveis pelíticos e psamíticos, as variações verticais e horizontais na textura dos saprolitos são também significativas, desde arenosa até argilosa. Predomina, de forma geral, a textura síltico-argilosa, em função do caráter pelítico das unidades $\mathrm{R}_{4}$ e PPC. Apesar disso, os saprolitos da região apresentam variados graus de laterização e diferentes características de permeabilidade. Possivelmente a condutividade hidráulica dos saprolitos de quartzitos é elevada. Contudo, naqueles originários dos metapelitos, que apresentam elevado grau de laterização, a permeabilidade deve ser bastante baixa.

$\mathrm{Na}$ área de estudo não existem informações de perfis geológicos de poços profundos na região onde afloram os 
filitos pertencentes ao Grupo Canastra. Observações de campo indicam que a maior parte desta área é recoberta por um manto espesso, comparável àquele que ocorre sobre as litologias do Grupo Paranoá. Próximo ao rio São Bartolomeu o relevo então plano, passa a exibir morros côncavo-convexos e vales encaixados. Nesta região os solos são pedregosos e bastante rasos, correspondendo aos cambissolos descritos pela EMBRAPA (1978). Em função da sua pequena profundidade e do substrato de caráter argiloso, possivelmente o manto de intemperismo apresenta baixa permeabilidade.

\section{Domínio Fraturado}

As rochas metassedimentares dos Grupos Paranoá e Canastra representam meios tipicamente fraturados. Os espaços intergranulares destas rochas foram fechados durante o metamorfismo e são praticamente insignificantes. Os condicionantes em subsuperfície do fluxo da água são representados principalmente por fraturas, responsáveis pela permeabilidade secundária destas rochas.

Com base nas principais unidades litoestratigráficas e considerando critérios litológicos e as características hidráulicas (vazão e capacidade específica) dos poços profundos, foi possível definir na área de estudo 2 sistemas aquífferos: Sistema Paranoá e Sistema Canastra. O Sistema Paranoá foi subdividido em 4 subsistemas. No Sistema Canastra não foram cadastrados poços profundos e, por isso, a sua caracterização se baseia em estudos hidrogeológicos realizados em outras áreas.

A média da capacidade específica dos poços em aquíf́eros fraturados é significativamente alta devido à existência de alguns poços com altas produtividades. A mediana da capacidade específica dos poços, quando comparada com a média, é portanto, mais representativa (Fernandes, 1997). Por isso optou-se, na caracterização dos parâmetros hidráulicos dos poços dos subsistemas aquíferos, pela utilização da média das vazões e mediana das capacidades específicas.

O domínio fraturado na região apresenta-se tipicamente anisotrópico e heterogêneo, que é materializado pelas significativas variações nas vazões entre poços separados por distâncias de algumas dezenas de metros. Estes aqüíferos na área são condicionados essencialmente pela presença de zonas fraturadas e formam aquíferos livres, com extensão lateral e vertical variáveis.

As águas subterrâneas deste domínio representam importante fonte de abastecimento para uma significativa parte da população da bacia, através de poços profundos.

\section{Sistema Paranoá}

\section{A) Subsistema Metarritmito Arenoso}

Este subsistema aquífero só é explotado na região nordeste da área de estudo no qual ocorre a unidade Metarritmito Arenoso $\left(\mathrm{R}_{3}\right)$ do Grupo Paranoá. Litologicamente este subsistema é constituído pela alternância de níveis centimétricos de metassiltitos, metassiltitos argilosos e metargilitos, e níveis centimétricos a métricos de quartzitos finos, laminados, que podem formar bancos de até $18 \mathrm{~m}$ de espessura.

A vazão média dos poços deste subsistema é de 26,7 $\mathrm{m}^{3} / \mathrm{h}$ (Tabela 1). A mediana da capacidade específica é de $0,80 \mathrm{~m}^{3} / \mathrm{h} . \mathrm{m}$. Os poços apresentam profundidades entre 154 e 186 m, com média de $173,5 \mathrm{~m}$.

\section{B) Subsistema Quartzito}

Este subsistema aquífero ocupa as áreas mais elevadas da chapada da Contagem e corresponde às litologias da unidade $\mathrm{Q}_{3}$ do Grupo Paranoá, denominada de Quartzitos Médios. Apresenta grande importância na área de estudo, pois corresponde aos locais onde existe grande demanda por água subterrânea, já que são áreas de topografia plana que favorece a ocupação antrópica e onde tem havido um grande adensamento populacional nos últimos anos.

Foram reconhecidos nesta unidade aqüífera, do ponto de vista litológico, quartzitos de granulação fina a média, bastante silicificados. Localmente ocorrem lentes de metarritmitos com espessuras variando desde decimétrica a métrica, tendo sido identificada uma lente com $9 \mathrm{~m}$ de espessura.

É possível estimar uma espessura média aparente de 130 m para este subsistema aqüífero. É importante ressaltar que este valor é bastante superior à espessura de $70 \mathrm{~m}$, proposta regionalmente para a unidade $\mathrm{Q}_{3}$ (Campos \& Freitas-Silva, 1998). A espessura calculada através dos poços pode ser considerada aparente em função da presença das estruturas em rampa e patamar, geradas durante a sedimentação das rochas da região, que mascaram a espessura real da unidade.

Os poços que explotam este subsistema apresentaram média de vazões de $8,7 \mathrm{~m}^{3} / \mathrm{h}$ e profundidades entre $0 \mathrm{e}$ 198,5 m, com média de $112 \mathrm{~m}$. A incidência de poços secos neste subsistema é praticamente nula, embora tenham sido identificados poços com baixas vazões, em torno de $1 \mathrm{~m}^{3} / \mathrm{h}$. A mediana da capacidade específica dos poços deste subsistema é de $0,24 \mathrm{~m}^{3} / \mathrm{h} . \mathrm{m}$ (Tabela 2). 


\section{C) Subsistema Metarritmito Argiloso}

Este subsistema ocorre na região de encosta, ou seja, na transição entre as porções mais elevadas de chapada (unidades $\mathrm{Q}_{3}$ e $\mathrm{R}_{3}$ ) e o vale no qual ocorre a unidade PPC. É correlacionável aos litotipos dos metarritmitos argilosos do Grupo Paranoá (unidade $\mathrm{R}_{4}$ ).

O subsistema é representado por um metarritmito bastante homogêneo no qual se alternam níveis centimétricos de metargilitos e metassiltitos. Freqüentemente estas litologias apresentam aspecto maciço. Ocorrem intercalados a este pacote lentes ou níveis de quartzitos finos, localmente médios, com espessuras centimétricas a até $2 \mathrm{~m}$. Cinco poços observados neste subsistema atingiram os quartzitos pertencentes ao Subsistema Quartzito, o que permitiu determinar uma espessura mínima de $105 \mathrm{~m}$ para a unidade aqüífera.

A Tabela 3 apresenta os principais parâmetros de vazão e capacidade específica dos poços que explotam o subsistema aqüífero Metarritmito Argiloso e os poços mistos (subsistemas Metarritmito Argiloso e Quartzito). A média de vazão dos poços no subsistema Metarritmito Argiloso é de $4,6 \mathrm{~m}^{3} / \mathrm{h}$ e a mediana da capacidade específica é de $0,08 \mathrm{~m}^{3} / \mathrm{h} . \mathrm{m}$. A incidência de poços secos é relativamente elevada, sendo a maior entre os subsistemas aqüíferos estudados. As profundidades dos poços estão entre 100 e $236,9 \mathrm{~m}$, apresentando média de $160 \mathrm{~m}$.

Tabela 1: Parâmetros hidráulicos dos poços do subsistema aqǘfero Metarritmito Arenoso.

\begin{tabular}{|c|c|c|c|c|c|c|c|}
\hline \multirow{2}{*}{$\begin{array}{c}\text { Subsistema } \\
\text { Aqüífero } \\
\text { Metarritmito } \\
\text { Arenoso }\end{array}$} & $\begin{array}{c}\text { Parâmetros } \\
\text { hidráulicos }\end{array}$ & Mánima & Média & Máxima & Mediana & $\begin{array}{c}\mathbf{N}^{0} \text { de poços em } \\
\text { funcionamento }\end{array}$ & $\begin{array}{c}\mathbf{N}^{0} \text { de poços } \\
\text { desativados }\end{array}$ \\
\cline { 2 - 6 } & $\begin{array}{c}\text { Capacidade específica } \\
\left(\mathrm{m}^{3} / \mathrm{h} . \mathrm{m}\right)\end{array}$ & 17,0 & 26,7 & 35,0 & - & 3 & 1 \\
\hline
\end{tabular}

Tabela 2: Parâmetros hidráulicos dos poços do subsistema aqǘfero Quartito.

\begin{tabular}{|c|c|c|c|c|c|c|c|}
\hline \multirow{2}{*}{$\begin{array}{c}\text { Subsistema } \\
\text { Aqüífero } \\
\text { Quartzito }\end{array}$} & Parâmetros hidráulicos & Mínima & Média & Máxima & Mediana & $\begin{array}{c}\mathrm{N}^{0} \text { de poços em } \\
\text { funcionamento }\end{array}$ & $\begin{array}{c}\mathrm{N}^{0} \text { de poços } \\
\text { desativados }\end{array}$ \\
\cline { 2 - 6 } & Vazão $\left(\mathrm{m}^{3} / \mathrm{h}\right)$ & 1,0 & 8,7 & 20,3 & - & 24 & 0 \\
\cline { 2 - 6 } & $\begin{array}{c}\text { Capacidade específica } \\
\left(\mathrm{m}^{3} / \mathrm{h} . \mathrm{m}\right)\end{array}$ & 0,01 & 0,86 & 7,25 & 0,24 & 24 & 0 \\
\hline
\end{tabular}

Tabela 3: Parâmetros hidráulicos dos poços dos subsistemas aqǘferos Metarritmito Argiloso e misto (Metarritmito Argiloso/Q uartito).

\begin{tabular}{|c|c|c|c|c|c|c|c|}
\hline $\begin{array}{l}\text { Subsistema } \\
\text { Aqüífero }\end{array}$ & Parâmetros hidráulicos & Mínima & Média & Máxima & Mediana & $\begin{array}{c}\text { Número de } \\
\text { poços em } \\
\text { funcionamento }\end{array}$ & $\begin{array}{c}\text { Número de poços } \\
\text { desativados }\end{array}$ \\
\hline \multirow{2}{*}{$\begin{array}{l}\text { Metarritmito } \\
\text { Argiloso }\end{array}$} & Vazão $\left(\mathrm{m}^{3} / \mathrm{h}\right)$ & 1,0 & 4,6 & 14,5 & - & \multirow{2}{*}{12} & \multirow{2}{*}{3} \\
\hline & $\begin{array}{l}\text { Capacidade específica } \\
\left(\mathrm{m}^{3} / \mathrm{h} . \mathrm{m}\right)\end{array}$ & 0,01 & 0,11 & 0,35 & 0,08 & & \\
\hline \multirow[t]{2}{*}{ Misto } & Vazão $\left(\mathrm{m}^{3} / \mathrm{h}\right)$ & 2,1 & 3,6 & 5,4 & - & \multirow{2}{*}{4} & \multirow{2}{*}{1} \\
\hline & $\begin{array}{l}\text { Capacidade específica } \\
\left(\mathrm{m}^{3} / \mathrm{h} . \mathrm{m}\right)\end{array}$ & 0,03 & 0,10 & 0,23 & 0,04 & & \\
\hline
\end{tabular}

Tabela 4: Parâmetros hidráulicos dos poços do subsistema aqǘfero Psamo-Pelito Carbonatado.

\begin{tabular}{|c|c|c|c|c|c|c|c|}
\hline \multirow{2}{*}{$\begin{array}{c}\text { Subsistema } \\
\text { Aqüífero } \\
\begin{array}{c}\text { Psamo-Pelito } \\
\text { Carbonatado }\end{array}\end{array}$} & Parâmetros hidráulicos & Mínima & Média & Máxima & Mediana & $\begin{array}{c}\text { Número de poços em } \\
\text { funcionamento }\end{array}$ & $\begin{array}{c}\text { Número de poços } \\
\text { desativados }\end{array}$ \\
\cline { 2 - 6 } & $\begin{array}{c}\text { Capacidade específica } \\
\left(\mathrm{m}^{3} / \mathrm{h} . \mathrm{m}\right)\end{array}$ & 0,13 & 0,71 & 1,38 & 0,51 & \multirow{2}{*}{15} & 3 \\
\hline
\end{tabular}




\section{D) SubsistemaPsamo-Pelito Carbonatado}

Os poços que atravessam este subsistema na área de estudo concentram-se na porção norte da bacia, que corresponde à região do assentamento Sobradinho II e condomínios próximos. As litologias descritas são correlacionáveis à unidade PPC de topo do Grupo Paranoá.

Este subsistema é representado basicamente por metassiltitos argilosos e metargilitos bastante laminados. São observadas lentes de meta-calcários cinza escuros interdigitadas neste pacote, de espessura métrica atingindo até $20 \mathrm{~m}$. A característica importante, sob o aspecto litológico, do subsistema aqüífero na área de estudo, é a expressiva participação de quartzitos, que formam níveis ou lentes centimétricas a métricas.

As profundidades dos poços neste subsistema aqüífero estão entre 85 e 140 m, com média de $115 \mathrm{~m}$. A presença de camadas e lentes de quartzitos é responsável pela elevada média de vazão dos poços de $15,7 \mathrm{~m}^{3} / \mathrm{h}$ (Tabela 4). Entretanto, são também bastante freqüentes os poços secos quando são encontrados apenas tipos pelíticos, ou até mesmo onde se observam espessos níveis de quartzitos. Alguns destes poços secos apresentam perfis litológicos indicando a existência de expressivo fraturamento em quartzitos, que demonstra a importância, na produtividade dos poços, da presença de fraturas abertas e interconectadas com zonas de recarga.

Apenas 3 poços na área atravessaram camadas ou lentes de rochas calcárias, indicando que localmente podem se desenvolver na área aquíferos cárstico-fissurais. As feições de dissolução associada a fraturamento possivelmente são mais importantes nas lentes de maior espessura.

A Figura 5 apresenta um perfil hidrogeológico mostrando os subsistemas aqüíferos do Sistema Paraná.

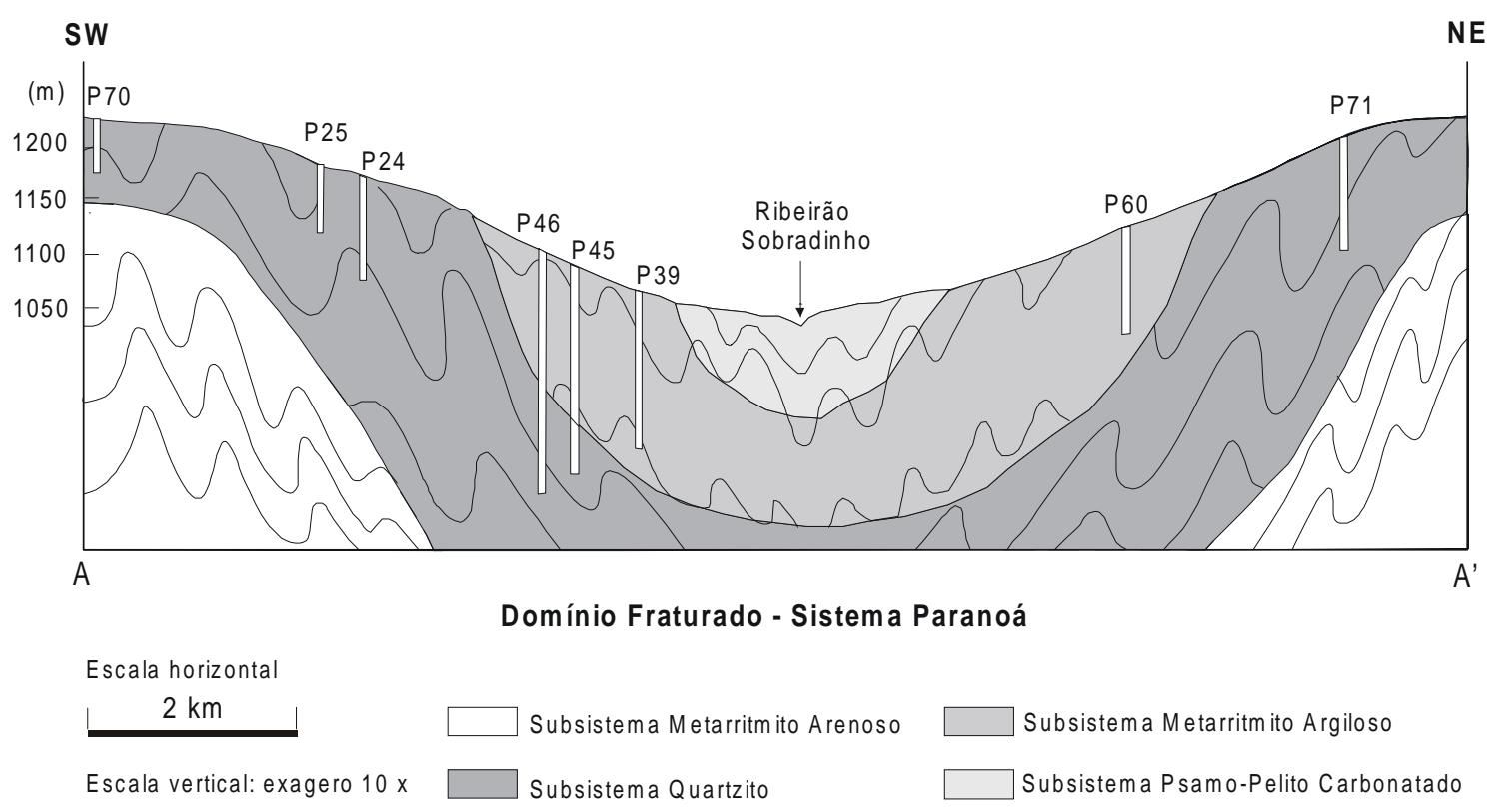

Figura 5: Perfil hidrogeológico esquemátic o transversalà área estuda da mostrando a estrutura em sinc linal da bacia do ribeirão Sobra dinho e osprincipa is subsistema sa qǘf́ros da área de estudo. (A orientação do perfil é mostrada na Figura 2). 


\section{Sistema Canastra}

É representado litologicamente pelos filitos do Grupo Canastra. Embora na região do DF tenham sido localmente descritas associações de lentes de mármores, calcifilitos e quartzitos interdigitados aos filitos, estes tipos litológicos não foram reconhecidos em afloramentos na área de estudo.

De acordo com Campos \& Freitas-Silva (1998), a vazão média deste subsistema é de $7,5 \mathrm{~m}^{3} / \mathrm{h}$, não sendo rara a incidência de poços com baixas vazões. O relevo em geral acidentado, associado a solos pouco profundos e pouco permeáveis, dificultam a infiltração e a recarga do aqüífero.

\section{Caracterização do Fraturamento}

$\mathrm{Na}$ área de estudo em afloramentos foi caracterizada a presença de 4 grandes famílias de fraturas com direções N5W, N30E, N54W e N53E, e cuja gênese foi relacionada às fases $F_{2}$ e $F_{3}$, que representam a principal deformação observada nas litologias da área. As famílias de fraturas N5W e N30E correspondem, em geral, a fraturas de extensão, e as famílias N54W e N53E a fraturas de cisalhamento.

Predominam amplamente na região as fraturas subverticais $\left(80\right.$ a $90^{\circ}$ ), com um total de $51,3 \%$, e as de alto mergulho com $40,6 \%\left(60\right.$ a $\left.80^{\circ}\right)$. As fraturas com mergulhos inferiores a $60^{\circ}$ perfazem apenas $8,1 \%$.

As famílias N5W e N30E são dominadas essencialmente por fraturas de alto ângulo a subverticais. Os planos destas fraturas estão freqüentemente preenchidos por quartzo maciço, indicando sua natureza extensional. As famílias de fraturas com direção N54W e N53E, embora dominadas por ângulos altos de mergulhos, apresentam valores relativamente inferiores às outras 2 famílias. A família N54W é a única com mergulho bem definido, para SW. São fraturas de cisalhamento que formam um par conjugado e são bem expressivas em lineamentos fotointerpretados.

As fraturas geradas nas fases mais tardias de deformação $\left(\mathrm{F}_{4}\right.$ e $\left.\mathrm{F}_{5}\right)$ são estatisticamente pouco representativas na área estudada. Elas são representadas pelas famílias de direção N-S e N75-85W. Esta última aparece bem definida como lineamento no trecho superior do ribeirão Sobradinho, próximo à sua nascente, e na região de confluência com o rio São Bartolomeu.

Não foi possível identificar na área de estudo evidências de reativações tectônicas posteriores àquelas relacionadas ao Ciclo Brasiliano (650 Ma). Embora a mega- estruturação observada na paisagem da área de estudo esteja condicionada às estrutura de idade proterozóica, é possível que eventos tectônicos posteriores tenham reativado os grandes sistemas de fraturamento identificados na área.

\section{Avaliação do Aqüífero Fraturado}

\section{Profundidade dasentradas de água}

Em apenas 29 poços cadastrados haviam informações confiáveis quanto às profundidades das entradas de água (EA) nos poços. As informações quanto a entradas de águas nos subsistemas metarritmitos argiloso e arenoso não podem ser consideradas conclusivas em função do pequeno número de poços avaliados. Entretanto, algumas observações podem ser feitas.

A profundidade na qual se iniciam as EA são relativamente profundas, a partir dos $40 \mathrm{~m}$, já que nestes subsistemas o manto de intemperismo é bastante espesso, obrigando o revestimento de uma significativa parte da porção superior do poço. Foi observado que os níveis com fraturamento mais expressivos e no qual ocorrem as fraturas mais produtoras de água, estão associados às camadas ou lentes de quartzitos. Esta característica pode ser estendida a todos os demais subsistemas aqǘferos, sendo a presença de EA associadas a metassiltitos e metargilitos menos expressiva e importante. Por isso, por exemplo, no subsistema Metarritmito Argiloso são detectadas EA desde 41 até $200 \mathrm{~m}$ de profundidade, já que os quartzitos ocorrem nas mais diversas posições estratigráficas dentro do conjunto predominantemente argiloso (Figura 6). Nos subsistemas Quartzito e Psamo-Pelito Carbonatado fica evidente que as maiores concentrações de EA, correspondendo a mais de $85 \%$, ocorrem entre 21 e $100 \mathrm{~m}$ (Figura 6).

\section{Relação produtividade dospoçose lineamentos}

Em função das significativas variações de vazão e capacidade específica entre os subsistemas aqüíferos estudados, a análise da relação produtividade dos poços e lineamentos foi realizada separadamente para cada subsistema. Deste modo, buscou-se avaliar a influência do lineamento para um mesmo tipo litológico.

Foi escolhida para esta análise a capacidade específica, que vem sendo utilizado como parâmetro indicativo da produtividade de poços em aqüíferos fraturados (Fernandes, 1997; Knopman \& Hollyday, 1993). Foram extraídos em fotografias aéreas de escala 1:40.000 todos 
Subsistema Metarritmito Arenoso

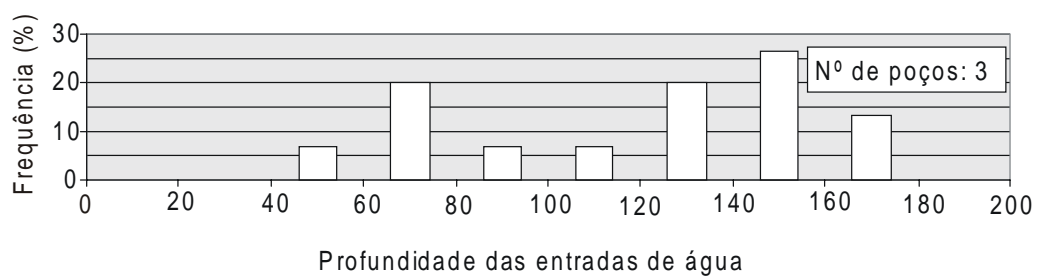

Subsistema Quartzito

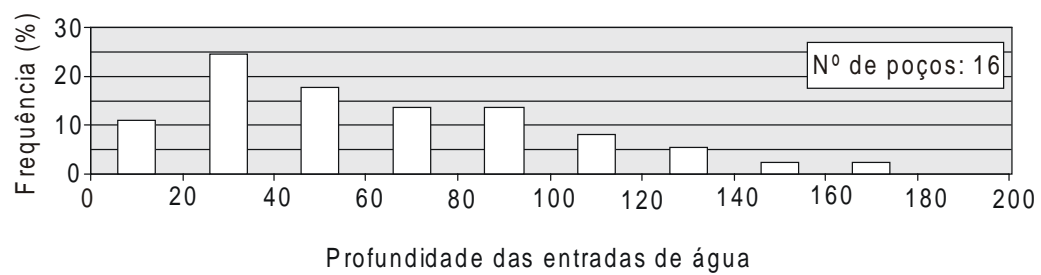

Subsistema Metarritmito Argiloso

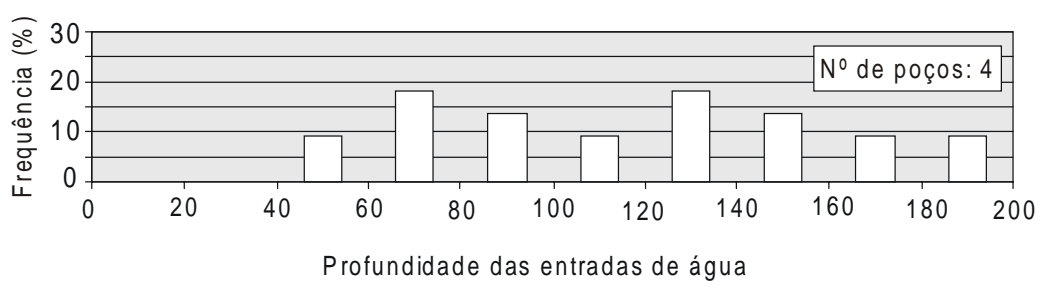

Subsistema Psamo-Pelito Carbonatado

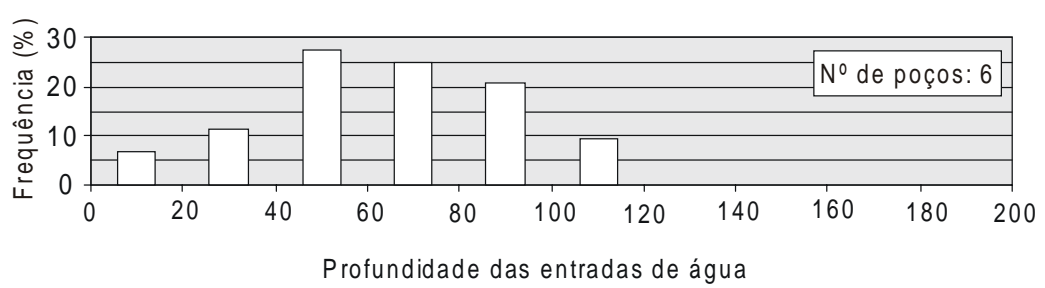

Figura 6: Profundida de dasentrada sde água (metros) nossubsistemasaqǘferosestudados. 
os elementos fortemente estruturados que possivelmente refletem descontinuidades em subsuperfície, interpretadas como fraturas.

Foi observada a dificuldade em relacionar a produtividade dos poços aos lineamentos fotointerpretados na área de estudo, apesar de terem sido caracterizadas, através da análise do fraturamento, as fraturas abertas. Alguns aspectos podem ter contribuído para este resultado. O manto de intemperismo, associado a um relevo plano a suavemente ondulado, mascara algumas fraturas em subsuperfície. Além disso, os poços utilizados no estudo não apresentam distribuição homogênea ao longo da região, concentrando-se na porção norte da área de estudo. Desta forma a análise ficou praticamente restrita àquela área.

\section{Critérios para locação de poços}

Os aquífferos fraturados na área estudada apresentam forte controle litológico, em função das diferenças de comportamento reológico das litologias durante a deformação rúptil. As variações de competência entre as rochas refletem diretamente no padrão de fraturamento.

Os quartzitos são as litologias mais competentes e apresentam comportamento rúptil, produzindo uma razoável densidade de fraturas abertas, que pode ser observada em afloramentos. Os metassiltitos e metargilitos apresentam comportamento mais plástico e dúctil que os quartzitos. Apesar de terem sido submetidos às mesmas condições de metamorfismo e deformação, em função da sua maior plasticidade, apresentam menor densidade de fraturas e os planos de fraturamento tendem a serem mais fechados. Os filitos do Grupo Canastra apresentam alta plasticidade e baixa permeabilidade, que é evidenciada pela alta densidade de drenagem em fotos aéreas e manto de intemperismo delgado e argiloso. Por isso, também apresentam condições pouco favoráveis para a transmissão e o armazenamento de água.

$\mathrm{O}$ critério geomorfológico pode ser aplicado à área estudada, sendo diretamente correlacionável ao fator litologia. Isto porque as unidades com predomínio da fração psamítica, principalmente quartzitos, correspondem aos subsistemas aqüíferos Quartzito e Metarritmito Arenoso, que ocorrem nas áreas mais elevadas da região e apresentam poços com boas vazões. Na região de vale podem ser obtidas elevadas produtividades dos poços apenas onde são atingidas expressivas camadas ou lentes de quartzitos do subsistema aqüífero Psamo-Pelito Carbonatado.

Embora não tenha sido possível relacionar a produti- vidade dos poços ao tipo de lineamento, em função da gênese do fraturamento, os sistemas de fraturas N5W e $\mathrm{N} 30 \mathrm{E}$, por sua natureza extensional, podem formar bons aqüíferos. Considerando apenas os sistemas de deformação rúpteis, os sistemas de fraturas N-S e N75-85W também são favoráveis. Embora nem sempre seja possível identificar no campo lineamentos associados a estas famílias de fraturas, estudos geofísicos poderão auxiliar na sua identificação, fornecendo subsídios para a locação de poços.

\section{Aspectos da recarga e escoamento}

A recarga dos aqüíferos estudados é basicamente função da precipitação pluviométrica e das características físicas da bacia (relevo e tipo de solo), que determinam o volume que efetivamente infiltra no subsolo. Os domínios poroso e fraturado apresentam condições próprias de recarga, circulação e descarga.

\section{Domínio Poroso}

A principal fonte de recarga das águas do manto de intemperismo é a precipitação pluviométrica. Os dados obtidos através do balanço hídrico indicam que $28 \%$ da precipitação pluviométrica anual infiltra no subsolo, atingindo o aqüífero.

Na região norte da bacia, ocupada principalmente pelos condomínios, no qual se concentram os usuários de poços profundos, a água retirada do domínio fraturado é importante fonte de alimentação para o domínio poroso. Como nesse locais não existe rede coletora de esgotos, as águas residuárias são infiltradas no solo através de fossas sépticas ou negras. Desta forma, a água do meio fraturado é restituída ao manto poroso. Subordinadamente, a irrigação em algumas chácaras que empregam água de córregos, contribui como fonte de alimentação do aqüífero.

Como as porções topograficamente mais elevadas da bacia correspondem a áreas no qual o manto de intemperismo tem grande contribuição da alteração de quartzitos (unidades $\mathrm{R}_{3}$ e $\mathrm{Q}_{3}$ ), as características de elevada permeabilidade e relevo favorecem a infiltração nas zonas de recarga. As condições de recarga entretanto, não são favoráveis na região do vale dissecado do São Bartolomeu, no qual um relevo com declividades mais acentuadas (chegam a ser maiores que 20\%) associadas a um manto de intemperismo raso e pouco permeável, são pouco favoráveis à infiltração.

Um aspecto importante a ser destacado é que atualmente existe uma elevada taxa de ocupação na região nor- 
te da bacia, principalmente nas regiões topograficamente mais elevadas. O nível de ocupação destas áreas tem aumentado nos últimos anos resultando na formação de aglomerados urbanos, que estão se consolidando cada vez mais através da pavimentação de ruas e construções, com redução da área verde, produzindo significativa impermeabilização de amplas áreas do terreno. Por isso, é possível diagnosticar um aumento do escoamento superficial nestas regiões e redução da infiltração. A redução da taxa de recarga do aqüífero nestes locais pode ser considerada preocupante, em função do elevado consumo de água subterrânea através de poços profundos nos condomínios.

As principais zonas de descarga do domínio poroso na área são o ribeirão Sobradinho e, secundariamente, os córregos Paranoazinho, Capão Grande e Capão Comprido. A perenidade destas drenagens se deve à restituição do aqüífero do manto de intemperismo.

As fontes observadas na área de estudo são de contato e ocorrem nos locais de quebra de relevo, na transição entre as chapadas, de superfície plana, e a região de encosta com declividades mais elevadas. Nestes locais o nível freático aflora no contato entre o manto de intemperismo com o embasamento, meios de permeabilidades diferentes. São portanto, fontes relacionadas a fluxos locais e na grande maioria intermitentes, sendo aproveitadas por algumas chácaras e condomínios localizados, principalmente, na região norte da bacia.

A última importante zona de descarga do domínio poroso é representado pelo sistema fraturado subjacente. Neste caso o movimento descendente e, subordinadamente, lateral da água, garante a alimentação das descontinuidades físicas do meio rochoso, representadas principalmente pelas fraturas.

\section{Domínio Fraturado}

Em função do extenso manto de intemperismo que recobre a área, é possível afirmar que a alimentação do domínio fraturado diretamente por águas meteóricas deve ser muito restrita a inexistente. Por isso, o manto exerce papel fundamental sobre as condições de recarga das fraturas em subsuperfície, em função de fatores como espessura e permeabilidade. Além disso, no domínio fraturado ocorrem sistemas de fraturas com extensões restritas, na qual o manto sotoposto é responsável diretamente pela alimentação das fraturas, sendo muitas vezes mais importante do que a recarga em regiões topograficamente mais elevadas.

Em áreas de ocorrência dos subsistemas aqǘferos Metarritmito Arenoso e Quartzito, nos quais solo e saprolito têm caráter predominantemente arenoso e os processos de laterização são, em geral, incipientes, existem condições favoráveis para a recarga das fraturas. Por outro lado, nos subsistemas Metarritmito Argiloso e PsamoPelito Carbonatado, apesar da grande espessura do manto de intemperismo associado e da boa permeabilidade dos solos, as características hidráulicas dos saprolitos possivelmente exercem importante papel sobre a taxa de recarga do aqüífero subjacente, porque é nestes locais que ocorre o contato manto/fraturas. Naqueles locais onde o processo de laterização está avançado e a rocha mãe corresponde a metargilito e metassiltito as condições de recarga não são favoráveis.

$\mathrm{Na}$ área de ocorrência dos filitos do Grupo Canastra onde ocorrem solos delgados e relevo mais acidentado, a recarga através do manto de intemperismo, é muito pequena.

$\mathrm{Na}$ área de estudo não foi possível estabelecer com precisão os exutórios do domínio fraturado. Possivelmente, o principal exutório é representado pela rede de drenagem.

\section{Hidrogeoquímica}

Foram coletadas 50 amostras de água distribuídas entre 25 de poços tubulares profundos e 25 de poços rasos ou cacimbas. As análises físico-químicas e bacteriológicas tiveram como objetivo principal uma caracterização espacial da qualidade da água na área estudada.

As águas na área de estudo pertencem a um sistema de circulação local a intermediário, no qual a profundidade e o gradiente geotérmico não exercem qualquer influência sobre a sua temperatura. Desta forma observa-se que seus valores seguem a temperatura média da região $\left(23^{\circ} \mathrm{C}\right) \mathrm{com}$ as águas de cacimba e de poços apresentando valores médios respectivamente, de 22,3 e $24,4^{\circ} \mathrm{C}$.

A condutividade elétrica das águas analisadas é muito baixa, com $92 \%$ das amostras apresentando valores compreendidos entre 5,64 e 54,1 $\mathrm{S} / \mathrm{cm}$. Quatro amostras (8\%) apresentaram valores entre 108,2 e 198,3 $\mu \mathrm{S} / \mathrm{cm}$. Estes resultados indicam a baixa quantidade de íons dissolvidos nas águas estudadas.

As águas estudadas são pouco mineralizadas pois o manto de intemperismo intensamente lixiviado e o meio fraturado são formados basicamente por quartzo e argilominerais, como caulinita e ilita, minerais pobres em elementos como cálcio, magnésio e sódio. Os elementos dissolvidos nas águas da região provêm, principalmente, das águas de chuva e do solo. 
Estes aspectos ficam bastante evidenciados pelas baixas concentrações nas águas estudadas dos elementos maiores. Por isso, a maioria das amostras do aquífero fraturado apresentou concentrações de cálcio compreendidas entre 0,24 e 6,40 mg/L, com valor médio de 3,56 mg/L. Como o cálcio é um cátion de grande mobilidade, a sua remoção pelo intemperismo químico é muito fácil. Este aspecto fica evidente nas análises de água de poços rasos, que apresentaram valor médio de 2,4 mg/L. Em apenas 6 amostras $(12 \%)$ foram detectadas concentrações do íon magnésio com valores compreendidos entre 0,05 a $5,79 \mathrm{mg} / \mathrm{L}$. Nas águas de poços rasos a concentração média de sódio foi de $2,7 \mathrm{mg} / \mathrm{L}$, e nos poços profundos de $0,8 \mathrm{mg} / \mathrm{L}$. As concentrações do íon bicarbonato, principal ânion presente nas águas estudadas, também foram bastante baixas. Nas águas do manto de intemperismo a média foi de $8,39 \mathrm{mg} / \mathrm{L}$ e nas águas do aqüífero fraturado de $12,35 \mathrm{mg} / \mathrm{L}$.

As águas estudadas apresentam caráter ácido, sendo que $98 \%$ dos valores de $\mathrm{pH}$ estão compreendidos entre 4,5 e 6,5. Os valores médios de alcalinidade total das águas de poços rasos e poços profundos foram respectivamente, de 7,1 e $9,8 \mathrm{mg} / \mathrm{L}$ de $\mathrm{CaCO}_{3}$. Em relação à dureza total, as análises realizadas mostraram que $98 \%$ das amostras de águas podem ser classificadas como muito brandas, pois seus valores estão compreendidos entre 0,6 e $60,4 \mathrm{mg} / \mathrm{L}$ de $\mathrm{CaCO}_{3}$.

Como a principal fonte potencial de contaminação das águas subterrâneas na área estudada são as fossas, foi analisada a presença dos compostos de nitrogênio nas amostras coletadas. Das amostras analisadas 76\% apresentaram nitrogênio amoniacal abaixo do limite de detecção $(0,020 \mathrm{mg} / \mathrm{L})$. O valor médio da concentração das amostras no qual foi detectado o íon foi bastante baixo, com valores de $0,212 \mathrm{mg} / \mathrm{L}$ para poços rasos e $0,332 \mathrm{mg} / \mathrm{L}$, para águas de poços profundos. Entre os compostos de nitrogênio, os valores mais baixos foram os de nitrito, que em águas de poços rasos forneceram concentração média de $0,006 \mathrm{mg} / \mathrm{L}$ e em poços profundos de $0,004 \mathrm{mg} / \mathrm{L}$. Os nitritos estão presentes apenas em pequenas quantidades, porque são compostos transitórios, que em condições aeróbias logo são convertidos para nitratos. Como a origem do nitrogênio na água está relacionada principalmente aos processos que ocorrem próximos às zonas superficiais dos solos onde a matéria orgânica, as bactérias e o oxigênio são abundantes, as concentrações mais elevadas de nitrato foram obtidos em águas de poços rasos com um valor médio de 1,200 mg/L, chegando a um valor máximo de $5,175 \mathrm{mg} / \mathrm{L}$. Em amostras de poços profundos esses valores ficaram entre 0,040 e $0,690 \mathrm{mg} / \mathrm{L}$, com média de $0,195 \mathrm{mg} / \mathrm{L}$.
Em 4 poços rasos os valores de nitrato foram considerados elevados para as águas naturais da região (em geral inferiores a $1,000 \mathrm{mg} / \mathrm{L}$ ) e ficaram compreendidos entre 1,154 e $5,175 \mathrm{mg} / \mathrm{L}$. Três destas amostras, através de análises bacteriológicas, indicaram a presença de coliformes fecais, sugerindo que os valores de nitratos destas águas podem indicar contaminação por fossas.

Os valores de ferro total observados indicam que, apesar de considerado normalmente como elemento traço, o ferro é bastante comum nas águas da área de estudo. Embora, apresentem concentração média de $0,42 \mathrm{mg} / \mathrm{L}$, em $12 \%$ das amostras os valores foram superiores a $1,00 \mathrm{mg} /$ L. Estes resultados refletem o intemperismo químico bastante intenso atuante na região, pelo qual o ferro e o alumínio são concentrados pelo processo de laterização e podem, sob condições geoquímicas específicas, ceder o ferro para as águas subterrâneas.

\section{Classificação das águas}

De modo geral é possível estabelecer a seguinte relação de predominância iônica para as águas estudadas ( $\mathrm{r}$ miliequivalentes por litro):

- ânions: $\mathrm{r} \mathrm{HCO}_{3}^{-}>\mathrm{r} \mathrm{Cl}^{-}>\mathrm{r} \mathrm{SO}_{4}{ }^{2-}$;

- cátions: $\mathrm{r} \mathrm{Ca}^{2+}>\mathrm{r} \mathrm{Na}^{+}>\mathrm{r} \mathrm{Mg}^{2+}$.

A Figura 7 mostra que predominam amplamente as águas bicarbonatadas cálcicas. Subordinadamente, principalmente no manto de intemperismo, ocorrem águas com tendência bicarbonatada sódica e apenas uma amostra foi classificada como cloretada sódica.

\section{Qualidade das águas}

\section{Aspectos fisico-químicos}

O principal uso da água subterrânea na área de estudo é o domiciliar. De forma geral, a água é considerada potável quando pode ser consumida pelo homem sem riscos para sua saúde. Neste estudo foram adotadas como padrões de potabilidade de referência a portaria 036 do Ministério da Saúde de 1990 e a norma da Organização Mundial de Saúde (CETESB, 1990).

Como as águas estudadas apresentam baixo grau de salinização não foram observadas restrições, de forma geral, em relação aos principais parâmetros químicos analisados quando comparados às normas de potabilidade, sendo a única exceção o ferro total. Em relação às demais propriedades foram observados problemas em relação ao 


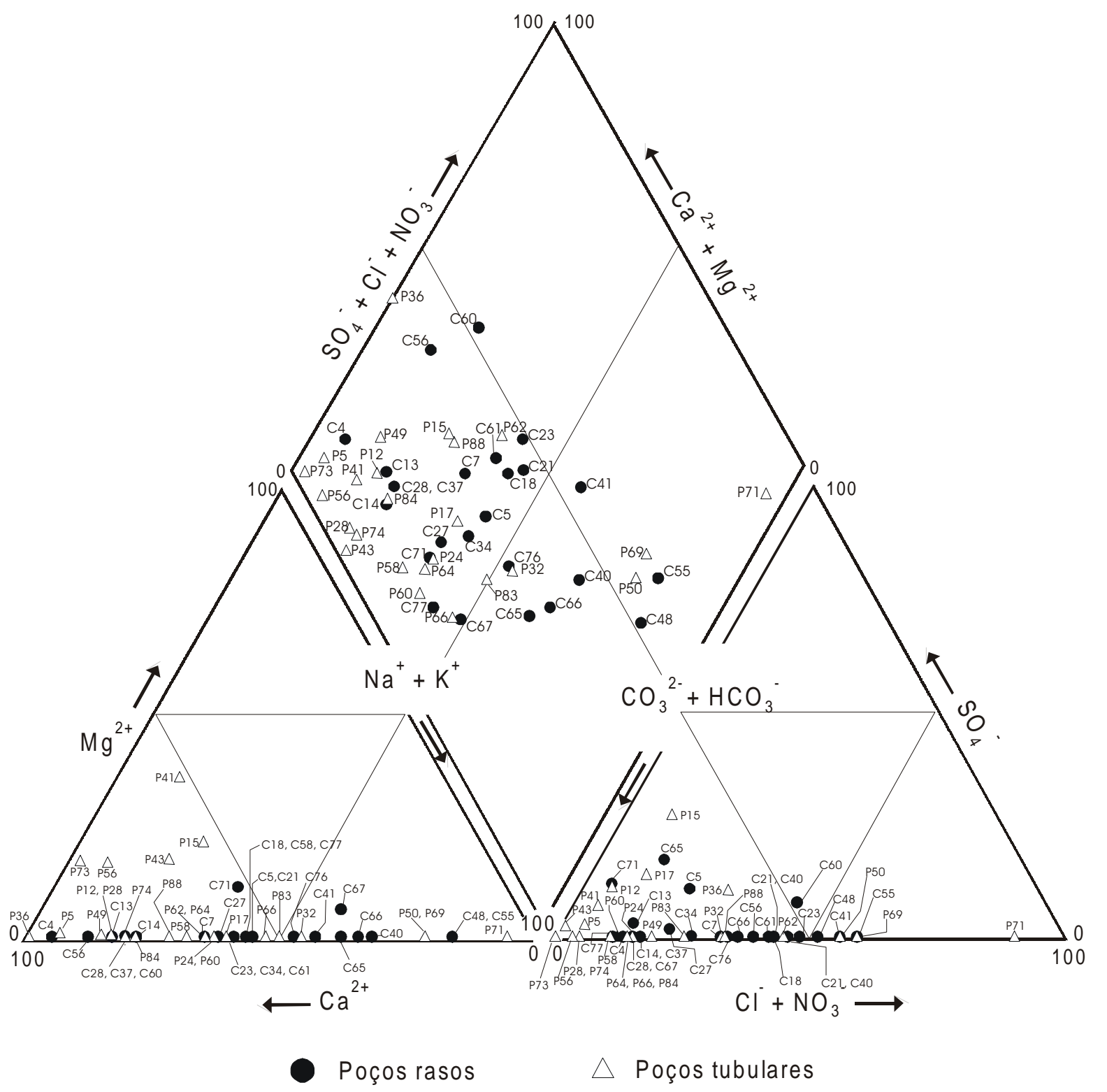

Figura 7: Diagrama de Piperpara classificação daságuassubterâneas.

pH. O teor de ferro é de considerável interesse para a qualidade das águas, pois afeta seriamente o seu uso para algumas finalidades domésticas e industriais. Os padrões de potabilidade estabelecem para a água potável um valor máximo de $0,3 \mathrm{mg} / \mathrm{L}$ de ferro total. Em $80 \%$ das amostras analisadas o valor de ferro total ficou acima deste limite. Convém observar que os valores máximos permitidos para o ferro nas águas são menores que a de muitos outros íons menores da água, e isso não se deve a razões fisiológicas, já que inclusive o corpo humano requer 5 a 6 miligramas de ferro por dia. O problema é que o ferro na água causa mancha nas instalações sanitárias e roupas lavadas, incrustações nos filtros de poços e obstrução nas canalizações pela formação de ferrugem e proliferação de bactérias.

Os valores de $\mathrm{pH}$ devem ficar dentro do intervalo de 6,5 a 8,5. Entretanto, $96 \%$ das amostras analisadas apresentaram valores inferiores a 6,5 . $\mathrm{O} \mathrm{pH}$ fora da faixa reco- 
mendada pode alterar o sabor da água contribuindo para a corrosão do sistema de distribuição de água, ocorrendo com isso, uma possível extração de elementos como ferro, cobre, chumbo, e zinco.

As águas analisadas, em termos práticos, podem ser consideradas adequadas ao consumo humano.

\section{Aspectobacteriológico}

As análises bacteriológicas em águas de poços tubulares revelaram que em nenhum poço foi detectada a presença de coliformes fecais. Estes resultados indicam que o aquífero fraturado está melhor protegido da contaminação, principalmente aquela originária da disposição de efluentes domésticos no terreno, que é a principal fonte de contaminação das águas na área de estudo. Em apenas 2 poços o NMP (número mais provável) de coliformes totais foi de $8 / 100 \mathrm{ml}$. A presença de coliformes totais detectados pode ser solucionada através da cloração e desinfecção dos poços, já que pelas observações de campo não existiam problemas de proximidade com fossas.

Das 25 análises de águas de poços rasos em apenas um poço raso não foi detectada a presença de coliformes. Esta amostra foi coletada de um poço raso bem construído, apresentando tampa de cimento e laje sanitária adequadas, revestimento em cimento e fossa bem afastada.

Nos demais poços foram detectadas a presença de coliformes totais (14 amostras) e coliformes totais e fecais (10 amostras). Os valores de contagem de coliformes totais em amostras com indicação de contaminação bacteriológica variaram de 13 até mais de 1600/100 ml, e os valores de coliformes fecais ficaram entre 2 e 300/100 ml.

Entre os poços no qual foi observada apenas a presença de coliformes totais, os principais problemas observados nos poços rasos no campo foram tampa ausente ou em estado precário, boca do poço sem altura mínima, poço sem revestimento ou parcialmente revestido, ausência de laje de proteção sanitária e utilização de balde com sarrilho. Estes aspectos construtivos das obras restringem as condições de higiene para a captação de água e criam condições para a proliferação de bactérias.

Em 6 poços rasos as observações de campo indicaram a possibilidade de contaminação fecal devido à proximidade de fossas, que no entanto não foi detectada pelas análises bacteriológicas. Em 5 destes casos os poços estão localizados em regiões onde o nível freático está a mais de $14 \mathrm{~m}$ de profundidade, o que pode indicar a boa capacidade de autodepuração da zona não saturada antes do efluente doméstico atingir o aqüífero.

Em 10 poços rasos foi detectada a presença simultânea de coliformes totais e fecais. Além das captações apre- sentarem problemas construtivos similares àqueles descritos anteriormente, existia o problema da proximidade fossa-poço, com distâncias variando entre 2 e $25 \mathrm{~m}$, de acordo com as observações de campo. Em um poço raso foi observada a maior contagem de coliformes fecais com 300/100 ml e concentração de nitrato de 5,1 mg/L, consideravelmente alto para a região.

\section{CONCLUSÕES}

A água subterrânea, especialmente a partir da década de 90, se tornou importante alternativa de abastecimento para uma significativa parcela da população da bacia do ribeirão Sobradinho. Esta demanda tem aumentado significativamente em função do processo de parcelamento do solo, que resultou na formação dos condomínios. De acordo com os dados levantados, pelo menos 22.500 pessoas dependem exclusivamente do recurso hídrico subterrâneo na área de estudo.

O Domínio Poroso está associado, na região, ao manto de intemperismo (solo e saprolito), sendo representado por aquífferos livres, de grande continuidade lateral. Os aqüíferos associados aos aluviões são restritos e pouco espessos, não apresentando importância no quadro hidrogeológico local. A espessura e permeabilidade do manto de intemperismo apresentam grande controle em função do substrato geológico. Como predominam na região as sequiências metarrítmicas, na qual se alternam pelitos e psamitos, as variações nas características hidráulicas do regolito são muito grandes.

O Domínio Poroso é explotado na região através de poços rasos, principalmente nas regiões central e sul da área de estudo, que apresentam ocupação de caráter predominante rural. O manto de intemperismo também desempenha importante função na manutenção da perenidade das drenagens da região, na proteção ao aqüífero à contaminação antrópica e na alimentação do aquíffero fraturado.

Devido ao forte controle litológico e estratigráfico observado nos aqüíferos fraturados, a classificação proposta seguiu a nomenclatura das principais unidades geológicas. O Subsistema Aqüífero Quartzito, em função da sua ampla distribuição e elevada média de vazões $\left(8,7 \mathrm{~m}^{3} /\right.$ h), apresenta grande importância na região. Os subsistemas aqüíferos Metarritmito Arenoso e Psamo-Pelito Carbonatado ocorrem em porções restritas da área de estudo, apresentando bom potencial hidrogeológico, evidenciado pelas elevadas vazões médias de 26,7 e $15,7 \mathrm{~m}^{3} / \mathrm{h}$, respectivamente. O Subsistema Metarritmito Argiloso, apesar da sua ampla distribuição, apresenta pequena vo- 
cação hídrica (vazão média de $4,6 \mathrm{~m}^{3} / \mathrm{h}$ ), evidenciada pela incidência de poços secos.

As condições de circulação da água no sistema fraturado da região estão condicionadas ao padrão de fraturamento das rochas. As principais fraturas produtoras nos poços ocorrem próximas à superfície, concentrando-se em profundidades até $100 \mathrm{~m}$. Embora não tenha sido possível relacionar a produtividade dos poços aos lineamentos fotointerpretados, estudos geofísicos em áreas selecionadas poderão auxiliar na identificação destas famílias de fraturas em subsuperfície. É recomendável que sejam aprofundados os estudos sobre a tectônica pósproterozóica no DF, que poderão fornecer novos subsídios para a prospecção nos aqüíferos fraturados.

O tipo litológico também exerce importante controle sobre a produtividade dos poços da região. O comportamento rúptil dos quartzitos favorece o desenvolvimento de uma razoável densidade de fraturas abertas, quando comparada aos metassiltitos, metargilitos e filitos, resultando em poços mais produtivos.

A recarga dos aqüíferos da região é função da precipitação pluviométrica, que na região estudada apresenta média anual de $1442,5 \mathrm{~mm}$. Cerca de $28 \%$ do volume precipitado participa efetivamente da recarga dos aqüíferos.

O principal uso da água subterrânea na região é o domiciliar, representado pelos grandes condomínios e chácaras. As águas dos aquíferos poroso e fraturado são de boa qualidade físico-química, não apresentando restrições quanto ao seu uso. Apresentam baixíssimo grau de mineralização em função da associação entre manto de intemperismo extremamente lixiviado e litologias que contêm minerais pobres em íons maiores.

A contaminação bacteriológica observada em amostras de água do manto de intemperismo está relacionada às deficiências construtivas dos poços rasos e à proximidade entre fossa e poço. A boa qualidade bacteriológica da água de poços profundos indica que o aqǘf́re fraturado está mais protegido da influência das fossas, a principal fonte de contaminação das águas subterrâneas da região.

Embora tenham sido identificados elevados níveis de contaminação bacteriológica, a utilização de poços rasos, pelo menos na região rural, não pode ser considerada inviável, desde que a obra de captação seja bem construída, apresentando uma distância mínima de $30 \mathrm{~m}$ da fossa. Entretanto, são comuns poços mal construídos apresentando diversos problemas, tais como revestimento interno parcial, ausência de laje de proteção sanitária e tampa sem oferecer vedação. Muitas vezes estes problemas refletem a falta de orientação técnica durante a construção do poço raso.
A preocupação em relação à gestão dos recursos hídricos no DF está expressa através da Lei ${ }^{\circ} 512$ de 28/7/ 93, que dispõe sobre a Política de Recursos Hídricos no Distrito Federal institui o Sistema de Gerenciamento de Recursos Hídricos - SIGRH. Entretanto, os controles sobre o uso e concessão da água subterrânea não estão ainda definidos claramente. Por isso, tem ocorrido um crescimento descontrolado do número de poços na região, sem levar em conta as características hidrogeológicas dos aqüíferos e a sustentabilidade do recurso hídrico. A área de recarga na região noroeste da área de estudo, por exemplo, é intensamente explotada através de poços profundos e encontra-se bastante ocupada e impermeabilizada, afetando as condições de realimentação dos aqüíferos. A área de ocorrência do Subsistema Aqüífero Metarritmito Argiloso está sendo intensamente explotada na região norte da bacia e têm surgido muitos problemas de poços secos e desativados por queda de vazão. Falta ainda também, uma legislação específica para a água subterrânea que regulamente o processo de outorga e fiscalização, de modo a exigir dos perfuradores de poços uma melhor qualificação técnica para elaboração da obra de captação.

\section{REFERÊNCIAS BIBLIOGRÁFICAS}

BLANCO, S.B. (1995) Aspectos de geologia de engenharia da escavação do Metrô de Brasília trecho Asa Sul. Brasília, 92 p. Dissertação (Mestrado) - Instituto de Geociências, Universidade de Brasília.

CAMPOS, J.E.G.; FREITAS SILVA, F.H.(1998). Hidrogeologia do Distrito Federal. In: Inventário Hidrogeológico e dos recursos hídricos superficiais do Distrito Federal. Brasília, IEMA/UnB/ SEMATEC. 66p.

CETESB - COMPANHIA DE TECNOLOGIA DE SANEAMENTO AMBIENTAL (1990) Compilação de padrões ambientais. São Paulo, CETESB. 8 p.

CICCO, V.; FARIA, A.J.; ARCOVA, F.C.S; SHIMOMICHI, P.Y. (1985) Determinação do balanço hídrico com emprego de bacia hidrográfica experimental em mata secundária. In: SIMPÓSIO BRASILEIRO DE HIDROLOGIA E RECURSOS HÍDRICOS, 6., São Paulo, 1985. Anais. São Paulo, ABRH. v. 3, p. 234-245.

CODEPLAN - COMPANHIA DE DESENVOLVIMENTO DO PLANALTO (1984) Atlas do Distrito Federal. Brasília, GDF. 78 p.

COIMBRA, A.R.S.R. (1987) Balanço hídrico preliminar 
do Distrito Federal. In: BARROS, J.G.C. (coord). Inventário hidrogeológico do Distrito Federal. Brasília, CAESB. v. 1, p. 50-78.

CUSTÓDIO, E.; LLAMAS, M.R. (eds) (1996). Hidrologia subterránea. Barcelona, Omega. v. 1, $1157 \mathrm{p}$.

EMBRAPA - EMPRESA BRASILEIRA DE PESQUISA AGROPECUÁRIA (1978) Levantamento e reconhecimento dos solos do Distrito Federal. Rio de Janeiro, SNCLS. Boletim Técnico EMBRAPA, n. 53.

FARIA, A. (1995). Estratigrafia e sistemas deposicionais do Grupo Paranoá nas áreas de Cristalina, Distrito Federal e São João D’Aliança-Alto Paraíso de Goiás. Brasília, 220 p. Tese (Doutorado) - Instituto de Geociências, Universidade de Brasília.

FERNANDES, A.J. (1997) Tectônica cenozóica na porção média da bacia do rio Piracicaba e sua aplicação à hidrogeologia. São Paulo, 244 p. Tese (Doutorado) - Instituto de Geociências, Universidade de Brasília.

FREITAS-SILVA, F.H.; CAMPOS, J.E.G. (1998) Geologia do Distrito Federal. In: INVENTÁRIO HIDROGEOLÓGICO E DOS RECURSOS HÍDRICOS SUPERFICIAIS DO DISTRITO FEDERAL. Brasília, IEMA/UnB/SEMATEC. (Relatório Técnico Parcial, n. 1).

GDF - GOVERNO DO DISTRITO FEDERAL (1996) Parcelamentos do solo em processo de regularização: Região Administrativa (RA) V Sobradinho. Brasília, GDF. v. 1. (Série Temática, Documento 4).
HARIDASAN, M. (1994). Solos. In: NOVAES PINTO, M. (coord.). Cerrado: caracterização, ocupação e perspectivas. 2. ed. Brasília, UnB. p. 321-344.

IPDF - INSTITUTO DE PLANEJAMENTO TERRITORIAL E URBANO DO DISTRITO FEDERAL (1996) Plano diretor de ordenamento territorial do Distrito Federal (PDOT). Brasília, IPDF.

KNOPMAN, D.S.; HOLLYDAY, E.F. (1993) Variation in specific capacity in fractured rocks, Pennsylvania. Ground Water, v. 31, n. 1, p. 135-145.

MARTINS, E.S.; CARDOSO, F.B.F.; GASPAR, J.C. (1994) Dados preliminares da geologia de perfis de intemperismo em cortes do Metrô, Águas Claras, DF. In: SIMPÓSIO DE GEOLOGIA DO CENTROOESTE, 4., Brasília, 1994. Resumos Expandidos. Brasília, SBG/NCO. p. 202-205.

MORTARI, D. (1994) Caracterização geotécnica e análise do processo evolutivo das erosões no Distrito Federal. Brasília, 210 p. Dissertação (Mestrado) - Faculdade de Tecnologia, Universidade de Brasília.

NOVAES PINTO, M. (1986). Superfícies de aplainamento na bacia do rio São Bartolomeu - Distrito Federal. Revista Brasileira de Geografia, v. 48, n.3, p.237-257.

NOVAES PINTO, M. (1994). Caracterização geomorfológica do Distrito Fedral. In: NOVAES PINTO, M. (coord). Cerrado: caracterização, ocupação e perspectivas. Brasília. UnB. 2.ed. p. 285-344.

PLANIDRO - PLANO DIRETOR (1970). Água subterrânea para fins de abastecimento de água $\mathrm{e}$ irrigação no DF. Brasília. (Relatório n. 6). 